Jurnal Keperawatan Silampari

Volume 3, Nomor 1, Desember 2019

e-ISSN: 2581-1975

p-ISSN: 2597-7482

DOI: https://doi.org/10.31539/jks.v3i1.848

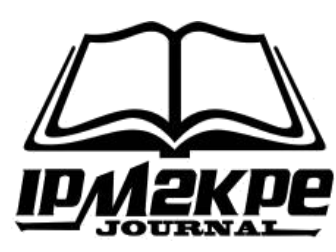

\title{
ANALISIS PENGARUH DUKUNGAN KELUARGA, DAN FAKTOR LAINNYA TERHADAP PEMBERIAN IMUNISASI MR PADA BALITA
}

\author{
Saka Adhijaya Pendit ${ }^{1}$, Tria Astika ${ }^{2}$, Nana Supriyatna ${ }^{3}$ \\ Program Studi Ilmu Keperawatan, STIKES Widya Nusantara Palu ${ }^{1}$ \\ Program Studi Magister Kesehatan Masyarakat, Universitas Muhammadiyah Jakarta² \\ Program Studi Keperawatan, Universitas Muhammadiyah Jakarta ${ }^{3}$ \\ Sakapendit@gmail.com ${ }^{1}$
}

\begin{abstract}
ABSTRAK
Penelitian ini bertujuan untuk mengetahui hubungan dukungan keluarga dan faktor lainnya dalam mengikuti imunisasi MR di Posyandu wilayah kerja Puskesmas Momunu Kabupaten Buol Sulawesi Tengah. Penelitian ini menggunakan desain cross sectional. Jumlah responden penelitian sebanyak 96 responden. Hasil penelitian ini menunjukkan bahwa ( $\mathrm{p}$ value 0.005 ) untuk variabel dukungan keluarga terhadap pemberian imunisasi $\mathrm{MR}$, untuk variabel dukungan perawat terhadap pemberian imunisasi MR ( $p$-value $0,007)$ dan untuk variabel pendidikan terhadap pemberian imunisasi MR ( $p$-value 0,012). Simpulan, ada hubungan yang signifikan antara dukungan keluarga terhadap pemberian imunisasi, ada hubungan dukungan perawat terhadap pemberian imunisasi dan ada hubungan pendidikan terhadap pemberian imunisasi.
\end{abstract}

Kata Kunci: Campak dan Rubella, Dukungan Keluarga, Pemberian Imunisasi MR

\section{ABSTRACT}

This study aims to determine the relationship of family support and other factors in participating in MR immunization in Posyandu in the work area of Momunu Health Center, Buol Regency, Central Sulawesi. This study uses a cross sectional design. The number of research respondents was 96 respondents. The results of this study indicate that ( $p$ value 0.005) for the variable family support for MR immunization, for the nurse support variable for MR immunization ( $p$-value 0.007) and for the education variable for MR immunization (p-value 0.012). Conclusion, there is a significant relationship between family support for [giving immunization, there is a relationship between nurse support for giving immunization and there is an educational relationship with giving immunization.

Keywords: Measles and Rubella, Family Support, Giving Immunization MR 


\section{PENDAHULUAN}

Imunisasi dalam sistem kesehatan nasional adalah salah satu bentuk intervensi kesehatan yang sangat efektif dalam upaya menurunkan angka kematian bayi dan balita. Imunisasi merupakan proses seseorang dibuat kebal atau resisten terhadap penyakit menular biasanya dengan pemberian vaksin (WHO, 2013). Program pemberian imunisasi merupakan salah satu upaya pemerintah dalam mengurangi angka morbiditas dan mortalitas anak agar tercapainya tujuan Millenium Development Goals (MDGs) tahun 2015 (Unicef, 2015).

Program MGDs kemudian akan berkelanjutan dengan program Sustainable Development Goals (SDGs) yang memiliki beberapa tujuan utama, yaitu untuk mengakhiri epedemi penyakit dan mencapai cangkupan kesehatan secara universal, kualitas akses pelayanan kesehatan yang penting serta vaksin untuk semua masyarakat dan juga imunisasi bukan hanya menjadi program kesehatan di Indonesia tetapi juga menjadi program di dunia World Health Organization (Unicef, 2015).

Campak merupakan penyakit yang sangat mudah menular yang disebabkan oleh virus dan ditularkan melalui batuk dan bersin. Gejala penyakit campak adalah demam tinggi, bercak kemerahan pada kulit (rash) disertai dengan batuk dan/atau pilek dan/atau konjungtivitis akan tetapi sangat berbahaya apabila disertai dengan komplikasi pneumonia, diare, meningitis dan bahkan dapat menyebabkan kematian. Penyakit ini sangat berpotensi menjadi wabah apabila cakupan imunisasi rendah dan kekebalan kelompok/herd immunity tidak terbentuk. Ketika seseorang terkena campak, 90\% orang yang berinteraksi erat dengan penderita dapat tertular jika mereka belum kebal terhadap campak. Seseorang dapat kebal jika telah diimunisasi atau terinfeksi virus campak (Kemenkes, 2017).

Pada tahun 2000, lebih dari 562.000 anak per tahun meninggal di seluruh dunia karena komplikasi penyakit campak. Dengan pemberian imunisasi campak dan berbagai upaya yang telah dilakukan, maka pada tahun 2014 kematian akibat campak menurun menjadi 115.000 per tahun, dengan perkiraan 314 anak per hari atau 13 kematian setiap jamnya (Kemenkes, 2017).

Di dunia data World Health Organization (WHO) menunjukan tahun 2015 terdapat 19,4 juta anak yang tidak mendapatkan imunisasi dan statistik menunjukkan bahwa hampir $85 \%$ bayi di dunia menerima vaksinasi lengkap. Data revelensi diantar negara di Dunia, pemberian imunisasi dasar lengkap dengan posisi tiga tertinggi pada tahun 2014 dan 2015 di dunia adalah Brazil 93\%, dan 96\%; India 85\%, dan 87\%; serta Ethopia $77 \%$, dan $86 \%$ sedangkan yang terendah dalam pemberian imunisasi dasar lengkap di tahun 2014 dan 2015 adalah Negara Equatorial Guinea 20\%, dan 16\% dan Indonesia menempati urutan ke- 4 dengan persentase $81 \%$ setelah negara Ethopia (WHO, 2016).

Campak dan Rubella merupakan penyakit infeksi menular melalui saluran nafas yang disebabkan oleh virus Campak dan Rubella (IDAI, 2017). Batuk dan bersin dapat menjadi jalur masuknya virus campak maupun rubella. Gejala campak muncul sekitar 10 hari setelah infeksi, dan ruam coklat kemerahan muncul sekitar 14 hari setelah infeksi (McGee, 2013). Gejala penyakit campak diantaranya demam tinggi, bercak kemerahan pada kulit (rash) dapat disertai batuk dan atau pilek maupun konjungtivitis serta dapat mengakibatkan kematian apabila terdapat komplikasi penyerta seperti pneumonia, diare, dan meningitis. Rubella merupakan masalah kesehatan yang mempunyai berbagai dampak klinis dan dapat memberikan dampak buruk baik berupa mortalitas dan morbiditas (Nazme, et al, 2014). 
Sebelum dilakukan imunisasi rubella, insidens CRS bervariasi antara 0,1-0,2/1000 kelahiran hidup pada periode endemik dan antara 0,8-4/1000 kelahiran hidup selama periode epidemi rubella. Angka kejadian CRS pada negara yang belum mengintroduksi vaksin rubella diperkirakan cukup tinggi. Pada tahun 1996 diperkirakan sekitar 22.000 anak lahir dengan CRS di regio Afrika, sekitar 46.000 di regio Asia Tenggara dan 12.634 di regio Pasifik Barat. Insiden CRS pada regio yang telah mengintroduksi vaksin rubella selama tahun 1996-2008 telah menurun (Kemenkes, 2017).

Sebelum dilakukan imunisasi rubella, insidens CRS bervariasi antara 0,1-0,2/1000 kelahiran hidup pada periode endemik dan antara 0,8-4/1000 kelahiran hidup selama periode epidemi rubella. Angka kejadian CRS pada negara yang belum mengintroduksi vaksin rubella diperkirakan cukup tinggi. Pada tahun 1996 diperkirakan sekitar 22.000 anak lahir dengan CRS di regio Afrika, sekitar 46.000 di regio Asia Tenggara dan 12.634 di regio Pasifik Barat. Insiden CRS pada regio yang telah mengintroduksi vaksin rubella selama tahun 1996-2008 telah menurun (Kemenkes, 2017).

Di Indonesia, rubella merupakah salah satu masalah kesehatan masyarakat yang memerlukan upaya pencegahan efektif. Data surveilans selama lima tahun terakhir menunjukan $70 \%$ kasus rubella terjadi pada kelompok usia $<15$ tahun. Selain itu, berdasarkan studi tentang estimasi beban penyakit CRS di Indonesia pada tahun 2013 diperkirakan terdapat 2767 kasus CRS, 82/100.000 terjadi pada usia ibu 15-19 tahun dan menurun menjadi 47/100.000 pada usia ibu 40-44 tahun. Sedangkan perhitungan modelling di Jawa Timur diperkirakan 700 bayi dilahirkan dengan CRS setiap tahunnya (Kemenkes, 2017).

Imunisasi di Indonesia merupakan program pemerintah yang wajib untuk dilaksanakan dengan capaian target hingga 100\%. Imunisasi MR merupakan program pengendalian penyakit yang di canangkan secara bertahap oleh pemerintah dengan capaian target 95\%. Dari hasil survey capain kampanye imunisasi MR Provinsi Sulawesi tengah sampai dengan tanggal 10 November 2018, Sulawesi Tengahmenjadi salah satu kota yang capainnya targetnya belum tercapai dengan presentasi $82,1 \%$. Kabupaten Buol merupakan salah satu kabupaten yang terdapat di provinsi sulawesi tengan yang memiliki cakupan target terendah dari kabupaten lainnya.

Rendahnya capaian Imunisasi MR dapat dipengaruhi oleh berbagai Factor. Di masyarakat yang sering mendengar pendapat yang salah mengenai imunisasi. Tidak jarang di jumpai orang tua yang ragu dan bahkan menolak imunisasi dengan berbagai alasan. Ketakutan atau penolakan imunisasi mungkin berdasarkan pengetahuan ibu, filosofi tertentu, keamanan dan efikasi vaksin, atau pandangan bahwa penyakit tidak menimbulkan masalah yang besar bagi kesehatan (Ranuh, 2008).

\section{METODE PENELITIAN}

Penelitian ini merupakan penelitian kualitatif dengan menggunakan desain cross sectional. Penelitian ini dilakukan pada bulan Maret hingga April 2019 yang dilaksanakan di wilayah kerja Puskesmas Momunu Kabupaten Buol Kecamatan Momunu. Populasi pada penelitian ini adalah anak balita yang berada di wilayah kerja puskesmas momunu kabupaten buol kecamatan momunu, dengan sampel penelitian sebanyak 96 orang ibu yang memiliki anak balita dengan kriteria inklusi sebagai berikut : balita yang tinggal dan menetap diwilayah kerja puskesmas momunu, balita yang rutin keposyandu dalam satu tahun terakhir, orangtua yang memiliki anak balita yang bisa membaca dan menulis. 
Teknik pengambilan sampel yang dilakukan adalah teknik random sampling. Data yang diperoleh selanjutnya dianalisis secra univariat bivariat dan multivariat menggunakan uji chi-square.

\section{HASIL PENELITIAN \\ Hasil Univariat Dan Bivariat}

Tabel. 1

Distribusi Karakteristik Responden terhadap Pemberian Imunisasi MR

\begin{tabular}{|c|c|c|c|}
\hline No & Variabel & Frekuensi n (\%) & Persentase $(100 \%)$ \\
\hline \multirow[t]{3}{*}{1} & Usia ibu & & \\
\hline & Muda (20-35) & 56 & 58,3 \\
\hline & Tua $(>35)$ & 40 & 41,7 \\
\hline \multirow[t]{3}{*}{2} & Pekerjaan & & \\
\hline & Tidak bekerja & 47 & 49,0 \\
\hline & bekerja & 49 & 51,0 \\
\hline \multirow[t]{3}{*}{3} & Penghasilan & & \\
\hline & Rendah & 69 & 71,9 \\
\hline & Tinggi & 27 & 28,1 \\
\hline \multirow[t]{3}{*}{4} & Pendidikan & & \\
\hline & Rendah & 49 & 51,0 \\
\hline & Tinggi & 47 & 49,0 \\
\hline \multirow[t]{3}{*}{5} & Dukungan Keluarga & & \\
\hline & Kurang & 53 & 55,2 \\
\hline & Baik & 43 & 44,8 \\
\hline \multirow[t]{3}{*}{6} & Pengetahuan & & \\
\hline & Kurang & 56 & 58,3 \\
\hline & Baik & 40 & 41,7 \\
\hline \multirow[t]{3}{*}{7} & Dukungan perawat & & \\
\hline & Kurang & 34 & 35,4 \\
\hline & Baik & 62 & 64,6 \\
\hline \multirow[t]{4}{*}{8} & Pemberian imunisasi & & \\
\hline & $\mathrm{MR}$ & 42 & 43,8 \\
\hline & Tdk diberikan & 54 & 56,3 \\
\hline & Diberikan & & \\
\hline
\end{tabular}

Tabel 1 menunjukan dari 96 ibu yang diambil sebagai responden, menunjukan bahwa ibu yang berusia muda (20-35tahun) presentasinya yaitu sebanyak 56 orang $(58,3 \%)$. Lebih dari separuh ibu memiliki pekerjaan yaitu sebagai pns dan pegawai honorer sebanyak 49 orang $(51,0 \%)$. Sebagian besar ibu yang menjadi responden memiliki penghasilan rendah yaitu 69 orang $(71,9 \%)$. Dan lebih dari separuh ibu berpendidikan rendah yaitu 49 orang $(51 \%)$.

Tabel 1 menunjukkan bahwa dari 96 ibu yang dijadikan responden, menunjukan kurangnya dukungan keluarga menjadi responden terbanyak yaitu 53 orang $(55,2 \%)$. Dan pengetahuan ibu tertinggi dengan pengetahuan kurang sebanyak 56 orang $(58,3 \%)$. Dukungan perawat dengan nilai baik sebanyak 62 orang $(64,6 \%)$.

Tabel 1 menunjukkan bahwa dari 96 ibu yang menjadi responden lebih dari separuh ibu telah melakukan imunisasi Measles Rubella pada anak balitanya yaitu $(56,3 \%)$. 
Tabel. 2

Hubungan Dukungan Keluarga dan Faktor Lainnya terhadap Pemberian Imunisasi MR

\begin{tabular}{|c|c|c|c|c|c|c|c|}
\hline \multirow{3}{*}{ Variabel } & \multicolumn{6}{|c|}{ Pemberian Imunisasi } & \multirow{3}{*}{$p$ value } \\
\hline & \multicolumn{2}{|c|}{ Tidak diberikan } & \multicolumn{2}{|c|}{ diberikan } & \multicolumn{2}{|c|}{ Total } & \\
\hline & $\mathrm{N}$ & $\%$ & $\mathrm{n}$ & $\%$ & $\mathrm{~N}$ & $\%$ & \\
\hline \multicolumn{8}{|l|}{ Dukungan Keluarga } \\
\hline Kurang & 32 & 60,4 & 21 & 39,6 & 53 & 100 & \multirow[b]{2}{*}{0,000} \\
\hline Baik & 10 & 23,3 & 23 & 76,7 & 43 & 100 & \\
\hline \multicolumn{8}{|l|}{ Pengetahuan } \\
\hline Kurang & 31 & 55,4 & 25 & 44,6 & 56 & 100 & \multirow[t]{2}{*}{0,007} \\
\hline Baik & 11 & 27,5 & 29 & 72,5 & 40 & 100 & \\
\hline \multicolumn{8}{|l|}{ Dukungan Perawat } \\
\hline Kurang & 22 & 64,7 & 12 & 35,3 & 34 & 100 & \multirow[t]{2}{*}{0,002} \\
\hline Baik & 20 & 32,3 & 42 & 67,7 & 62 & 100 & \\
\hline \multicolumn{8}{|l|}{ Usia } \\
\hline Muda & 23 & 41,1 & 23 & 58,9 & 56 & 100 & \multirow[t]{2}{*}{0,531} \\
\hline Tua & 19 & 47,5 & 21 & 52,5 & 40 & 100 & \\
\hline \multicolumn{8}{|l|}{ Pekerjaan } \\
\hline Tdk kerja & 24 & 51,1 & 23 & 48,9 & 42 & 100 & \multirow[t]{2}{*}{0,256} \\
\hline Bekerja & 18 & 36,7 & 31 & 63,3 & 54 & 100 & \\
\hline \multicolumn{8}{|l|}{ Pendidikan } \\
\hline Rendah & 28 & 58,3 & 20 & 41,7 & 42 & 100 & \multirow[t]{2}{*}{0,004} \\
\hline Tinggi & 14 & 29,2 & 34 & 70,8 & 54 & 100 & \\
\hline \multicolumn{8}{|l|}{ Penghasilan } \\
\hline Rendah & 29 & 42,0 & 40 & 58,0 & 69 & 100 & \multirow[t]{2}{*}{0,588} \\
\hline Tinggi & 13 & 48,1 & 14 & 51,9 & 27 & 100 & \\
\hline
\end{tabular}

Berdasarkan tabel 2 hasil uji statistic menggunakan chi square diperoleh Pvalue = 0,000 yang artinya ada hubungan yang signifikan antara dukungan keluarga dengan pemberian imunisasi measles rubella. Nilai OR sebesar 5,029 yang artinya dukungan keluarga responden yang baik mempunyai peluang 5,029 kali untuk diberikan pemberian imunisasi measles rubella.

Berdasarkan tabel 2 diatas hasil uji statistic menggunakan chi square diperoleh $\mathrm{p}$ value $=0,007$ yang artinya ada hubungan yang signifikan antara pengetahuan dengan pemberian imunisasi measles rubella. Nilai OR sebesar 3,269 yang artinya pengetahuanresponden yang baik mempunyai peluang 3,269 kali untuk diberikan pemebrian imunissi Measles Rubella.

Berdasarkan Tabel 2 diatas, menunjukkan hasil uji statistik menggunakan chi square diperoleh $\mathrm{p}$ value $=0,002$ yang artinya ada hubungan yang signifikan antara dukungan perawat terhadap pemberian imunisasi measles rubella. Nilai OR sebesar 3,850 yang artinya dukungan perawat yang baik mempunyai peluang 3,850 kali untuk diberikan terhadap pemberian imunisasi measles rubella.

Berdasarkan tabel 2 hasil uji statistic menggunakan chi square diperoleh $\mathrm{p}$ value $=$ 0,531 yang artinya tidak ada hubungan yang signifikan antara usia ibu dengan pemberian imunisasi measles rubella. Nilai OR sebesar 0,770.Berdasarkan Tabel 2 hasil uji statistic menggunakan chisquarediperoleh $\mathrm{p}$ value $=0,256$ yang artinya tidak ada hubungan yang signifikan antara pekerjaan dengan pemberian imunisasi Measles Rubella. Nilai OR sebesar 1,797. 
Berdasarkan tabel 2 hasil uji statistic menggunakan chi square diperoleh $\mathrm{p}$ value $=$ 0,0,004 yang artinya ada hubungan yang signifikan antara pendidikan dengan pemberian imunisasi measles rubella. Nilai OR sebesar 3,400 yang artinya pendidikan yang baik mempunyai peluang 3,400 kali untuk diberikan pemberian imunisasi measles rubella. Berdasarkan tabel 2 hasil uji statistic menggunakan chi square diperoleh $\mathrm{p}$ value $=0588$ yang artinya tidak ada hubungan yang signifikan antara penghasilan dengan pemberian imunisasi Measles Rubella. Nilai OR sebesar 0,781.

\section{Analisis Multivariat}

Analisis multivariat dilakukan bertujuan untuk mengetahui hubungan satu variabel atau beberapa variabel bebas dengan satu atau beberapa variabel tergantung. Bila hasil bivariat menghasilkan Pvalue $<0,25$ maka variabel tersebut langsung masuk ketahap multivariat. Uji ini menggunakan regresi logistik ganda.

Tabel. 3

Hasil Akhir pemodelan Multivariat Analisis dukungan keluarga dan faktor lainnya

\begin{tabular}{lccc}
\hline \multicolumn{1}{c}{ Variabel } & $\mathrm{B}$ & Pvalue & OR \\
\hline Dukungan keluarga & 1,372 & 0,005 & 3,943 \\
Dukungan perawat & 1,371 & 0,007 & 3,939 \\
Pendidikan & 1,236 & 0,012 & 3,442 \\
\hline
\end{tabular}

Berdasarkan pemodelan akhir analisa multivariat pada tabel 3 dengan menggunakan metode enter didapatkanvariabel yang berhubungan secara signifikan adalah dukungan keluarga dimana nilai $\mathrm{OR}=3,943$, yang berarti responden yang memiliki dukungan keluarga yang baik mempunyai peluang 3,943 kali terhadap pemberian imunisasi MR dibandingkan dengan responden dengan dukungan keluarga yang kurang baik. Dengan kekuatan hubungan dari yang terbesar ke yang terkecil adalah dukungan keluarga $(\mathrm{OR}=3,943)$, dukungan perawat $(\mathrm{OR}=3,939)$, dan pendidikan $(\mathrm{OR}=3,442)$.

\section{PEMBAHASAN}

\section{Hubungan Dukungan Keluarga terhadap Pemberian Imunisasi Measles Rubella}

Berdasarkan hasil penelitian yang dilakukan oleh peneliti mengenai hubungan antara dukungan keluarga terhadap pemberian imunisasi MR di Puskesmas Moumunu Kecamatan Buol Sulawesi Tengah diperoleh hasil dengan nilai $\mathrm{p}$ value sebesar 0,000 < 0,05 yang artinya ada hubungan yang signifikan antara dukungan keluarga terhadap pemberian imunisasi MR di Puskesmas Moumunu Kecamatan Buol Sulawesi Tengah.

Hal ini sejalan dengan penelitian Rahmawati, Umbul (2014) yang menunjukkan bahwa ada hubungan antara dukungan keluarga dengan kelengkapan imunisasi dasar dengan nilai $\mathrm{p}=0,000<0,05$. Penelitian yang dilakukan oleh Hidayah $\mathrm{N}$ (2017) tentang faktor yang berhubungan dengan pemberian imunisasi dasar lengkap pada bayi, menunjukkan bahwa ada hubungan dukungan keluarga terhadap pemberian imunisasi dasar lengkap pada bayi. Penelitian ini juga sejalan dengan penelitian yang dilakukan oleh Senewe (2017) yang menyatakan bahwa terdapat hubungan antara dukungan keluarga dengan kepatuhan ibu dalam pemberian imunisasi dasar. 
Respon positif keluarga responden terhadap pelaksanaan kegiatan imunisasi dipengaruhi oleh faktor pengetahuan yang baik yang dimiliki oleh keluarga responden \ tentang pentingnya imunisasi dasar pada anak yang tidak lain pengetahuan tersebut diperoleh dari informasi atau penyuluhan yang diberikan oleh petugas kesehatan. Petugas kesehatan menyadari bahwa dukungan keluarga sangat berperan penting terhadap keaktifan ibu dalam program imunisasi, sehingga sasaran penyuluhan tentang imunisasi pun selain ibu-ibu yang mempunyai anak juga keluarga bahkan ditujukan kepada seluruh masyarakat (Ismet, 2013).

Keluarga merupakan bagian terkecil dari masyarakat yang terdiri dari kepala keluarga dan anggota keluarga lainnya yang bertempat tinggal di dalam satu rumah karena adanya hubungan darah maupun ikatan pernikahan, sehingga terdapat interaksi antara anggota keluarga satu dengan anggota keluarga lainnya, apabila salah satu dari anggota keluarga memperoleh masalah kesehatan, maka akan dapat berpengaruh kepada anggota keluarga lainnya. Sehingga keluarga merupakan fokus pelayanan kesehatan yang strategis karena keluarga mempunyai peran utama dalam pemeliharaan kesehatan seluruh anggota keluarga, dan masalah keluarga saling berkaitan, keluarga juga dapat sebagai tempat pengambil keputusan dalam perawatan kesehatan (Mubarak, 2012).

\section{Hubungan Dukungan Perawat terhadap Pemberian Imunisasi Measles Rubella}

Berdasarkan hasil penelitian yang dilakukan oleh peneliti mengenai hubungan antara dukungan tenaga kesehatan terhadap pemberian imunisasi MR di Puskesmas Moumunu Kecamatan Buol Sulawesi Tengah diperoleh hasil dengan nilai $\mathrm{p}$ value sebesar 0,002 < 0,05 yang artinya ada hubungan yang signifikan antara dukungan tenaga kesehatan terhadap pemberian imunisasi MR di Puskesmas Moumunu Kecamatan Buol Sulawesi Tengah. Artinya, penelitian ini menunjukkan dukungan petugas mempengaruhi kepatuhan imunisasi sehingga sesuai dalam notoadmodjo (2007) bahwa peran tenaga kesehatan adalah sebagai customer, komunikator, fasilator, motivator, dan konselor.

Hasil penelitian ini sesuai dengan penelitian yang dilakukan Laila kusumawati (2006) yang mendapatkan hasil penelitian bahwa ada hubungan antara pelayanan petugas kesehatan terhadap kepatuhan imunisasi hepatitis B dengan nilai $\mathrm{p}$ value nya < 0,005 .

Pelayanan kesehatan adalah upaya yang diselenggarakan sendiri/secara bersamasama dalam suatu organisasi untuk memelihara dan meningkatkan kesehatan, mencegah, dan menyembuhkan penyakit serta memulihkan kesehatan perorangan, keluarga, kelompok atau masyarakat. Pelayanan kesehatan merupakan upaya yang diselenggarakan sendiri atau secara bersama-sama dalam suatu organisasi untuk memelihara dan meningkatkan kesehatan, mencegah dan menyembuhkan penyakit serta memulihkan kesehatan perorangan, keluarga, kelompok dan atupun masyarakat. Semakin bagus pelayanan kesehatan yang diberikan oleh tenaga kesehatan maka hal ini akan berdampak pada semakin meningkatnya derajat kesehata, begitu juga dengan imunisasi, semakin bagus pelayanan imunisasi yang didapatkan oleh orang tua dan bayi maka semakin besar cakupan pemberian imunisasi dasar lengkap (Triana, 2016). 


\section{Hubungan Pendidikan terhadap Pemberian Imunisasi Measles Rubella}

Berdasarkan hasil penelitian yang dilakukan oleh peneliti mengenai hubungan antara pendidikan terhadap pemberian imunisasi MR di Puskesmas Moumunu Kecamatan Buol Sulawesi Tengah diperoleh hasil dengan nilai $\mathrm{p}$ value sebesar 0,004 < 0,05 yang artinya ada hubungan yang signifikan antara pendidikan terhadap pemberian imunisasi MR di Puskesmas Moumunu Kecamatan Buol Sulawesi Tengah.

Penelitian yang dilakukan oleh Sarimin (2014) menunjukkan bahwa ada hubungan antara tingkat pendidikan ibu dengan perilaku ibu dalam pemberian imunisasi dasar pada balita di Desa Taraitak Satu Kecamatan Langowan Utara. Penelitian tersebut berbanding terbalik dengan penelitian yang dilakukan oleh Senewe et al, (2017) bahwa tidak terdapat hubungan pendidikan dengan kepatuhan ibu dalam pemberian imunisais dasar dengan $\mathrm{p} 0,451(\mathrm{p}<0,05 \%)$ hal ini karena pendidikan yang tinggi tidak menjamin pengetahuan yang didapat banyak.

Pendidikan formal, non formal, dan informal dapat mempengaruhi seseorang dalam mengambil keputusan dan berperilaku, dengan pendidikan seseorang dapat meningkatkan kematangan intelektual, sehingga dapat membuat keputusan dalam bertindak. Pendidikan formal merupakan pendidikan yang diselenggarakan di sekolahsekolah pada umumnya. Jalur ini mempunyai jenjang pendidikan yang jelas, mulai dari pendidikan dasar, pendidikan menengah, sampai pendidikan tinggi. Pendidikan nonformal paling banyak terdapat pada usia dini. Dan pendidikan informal adalah jalur pendidikan keluarga dan lingkungan berbentuk kegiatan belajar secara mandiri yang dilakukan secara sadar dan bertanggung jawab (Mulyana, 2006). Pendidikan adalah dasar untuk menyiapkan peserta didik melalui kegiatan bimbingan pengajaran dan latihan bagi perannya dimasa yang akan datang (Notoatmodjo, 2012), teori yang mengatakan semakin tinggi pendidikan semakin banyak pengetahuan yang didapatkan. Teori dan hasil penelitian yang didapatkan tidak sama, karena pendidikan yang tinggi tidak menjamin pengetahuan yang didapatkan banyak, sesuai hasil penelitian yang didapatkan pendidikan dari responden rendah tetapi responden patuh dalam pemberian imunisasi disebabkan oleh petugas kesehatan yang selalu memberikan penyuluhan tentang pentingnya imunisasi dasar kepada anak-anak.

Hal ini didukung oleh teori yang dikemukan oleh Wati (2013) Pendidikan diartikan sebagai tahapan kegiatan yang bersifat kelembagaan yang dipergunakan untuk menyempurnakan perkembangan individu dalam menguasai pengetahuan, kebiasaan, sikap dan sebagainya. Artinya semakin tingginya tingkat pendidikan seseorang maka akan semakin mudah menerima informasi sehingga banyak pula pengetahuan yang dimiliki. Sebaliknya pendidikan yang kurang akan menghambat perkembangan sikap seseorang terhadap hidup sehat.

\section{SIMPULAN}

Karakteristik responden Diwilayah Kerja Puskesmas Momunu Kecamatan Buol Sulawesi Tengah mayoritas usia ibu yang memiliki umur 20-35 tahun. Mayoritas pekerjaan ibu yaitu bekerja baik sebagai pns dan tenaga honorer ataupun wiraswasta dan petani. Mayoritas penghasilan ibu yang memiliki penghasilan rendah. Mayoritas pendidikan responden yang mimiliki pendidikan rendah.

Hasil analisis bivariat menunjukan bahwa terdapat empat variabel yang berhubungan dengan pemberian imunisasi measles rubella yaitu dukungan keluarga, pengetahuan, dukungan perawat, pendidikan. Sedangkan yang tidak berhubungan dengan pemberian imunisasi measles rubella adalah usia ibu, penghasilan, pekerjaan. 
Hasil analisis multivariat terdapat empat variabel yang masuk dalam seleksi kandidat yaitu, dukungan keluarga, pengetahuan, dukungan perawat, dan pendidikan. Dari empat hasil variabel pemodelan akhir multivariat model regresi logistik diketahui dukungan keluarga, dukungan keluarga dan pendidikan.

responden yang memiliki dukungan keluarga yang baik berpeluang 3,943 kali terhadap pemberian imunisasi measles rubella. Dukungan perawat yang baik berpeluang 3,939 kali terhadap pemberian imunisasi measles rubella dan pendidikan yang baik berpeluang 3,442 kali terhadap pemberian imunisasi measles rubella.

\section{SARAN}

1. Puskesmas

Dengan adanya penelitian ini diharapkan Puskesmas dapat meningkatan cakupan imunisasi MR di wilayah kerja Puskesmas Momunu Kabupaten Buol Sulawesi Tengah, karna mengingat cakupan imunisasi MR diwilayah ini masi kurang dari target pemerintah. Pentingnya dukungan keluarga dalam pemberian imunisasi MR perlu diperhatikan karena salah satu faktor minat ibu melakukan pemberian imunisasi MR dipengaruhi oleh dukungan keluarga yang baik.

2. Masyarakat / keluarga

Diharapkan ibu dan keluarga mengetahui pentingnya melakukan imunisasi Measles Rubella pada anak balita. Dan nantinya diharapkan ibu dapat menyetujui untuk melakukan imunisasi Measles Rubella pada anak balita mereka sehingga anak mereka mempunyai kekebalan tubuh yang baik terhadap virus.

3. Peneliti Selanjutnya

Penelitian ini diharapkan menjadi data dasar untuk penelitian berikutnya khususnya faktor budaya dapat diangkat menjadi salah satu faktor yang berpengaruh terhadap pemberian imunisasi Measles Rubella, karna di wilayah kerja Puskesmas Momunu Kecamatan Buol masi sangat kental mengenai ada istiadat dan kepercayaan mereka mengenai sesuatu termasukpemberian imunisasi measles rubella. Mungkin dalam penelitian selanjutnya peneliti bisa menggunakan metode kualitatif sehingga bisa menggali informasi lebih dalam mengenai faktor budaya terhadap pemberian imunisasi measles rubella.

\section{DAFTAR PUSTAKA}

Hidayah, N., Sihotang H. M., Lestari, W. (2018). Faktor yang Berhubungan dengan Pemberian Imunisasi Dasar Lengkap pada Bayi Tahun 2017. Jurnal Endurance, 3(1), 153-161. DOI: http://doi.org/10.22216/jen.v3i1.2820

IDAI. (2017). Imunisasi Campak-Rubella (MR). Dipetik Agustus 11, 2017, dari http://www.idai.or.id/artikel/klinik/imunisasi/imunisasi-campak-Rubellam

Ismet. (2013). Analisis Faktor-Faktor yang Berhubungan dengan Imunisasi Dasar Lengkap pada Bayi di Desa Botubarani Kecamatan Kabila Bone. Jurnal Keperawatan

Kemenkes. R. I. (2017). Petunjuk Teknis Kampamye Imunisasi Measles Rubella (MR)

Kusumawati, L. (2006). Faktor-Faktor yang Berhubungan dengan Pemberian Imunisasi Hepatitis B (0-7 hari) di Kabupaten Bantul, Fakultas Kesehatan Masyarakat. Universitas Gadjah Mada. Yogyakarta

Mandesa, E. M., Sarimin, D. S. \& Ismanto, A. Y. (2014). Pengaruh Pendidikan Kesehatan terhadap Pengetahuan dan Sikap Orangtua tentang Kejadian Ikutan Paska Imunisasi (KIPI). Ejournal Keperawatan 
McGee, P. (2013). Measles, Mumps, and Rubella. Diversity and Equality in Health and Care. Volume 10, pp. 123-5

Mubarak, W. I. (2012). Promosi Kesehatan untuk Kebidanan. Jakarta: Salemba Medika

Mulyana. (2006). Faktor-Faktor Ibu dan Balita yang Berhubungan dengan Kepatuhan. Jurnal Promosi Kesehatan Indonesia, 1(2)

Nazme, N. I., Hoque, M. M. \& Hussain, M. (2014). Congenital Rubella Syndrome: An Overview of Clinical Presentations in Bangladeshi Chlidren. Delta Med College, 2, pp. $42-47$

Notoatmodjo. (2012). Promosi Kesehatan dan Perilaku. Jakarta: Rineka Cipta

Notoatmodjo, S. (2007). Pendidikan dan Perilaku kesehatan. Cetakan 2. Jakarta: PT. Rineka Cipta

Rahmawati., Adzaniyah, I., Umbul, C. W. (2014). Faktor yang Mempengaruhi Kelengkapan Imunisasi Dasar di Kelurahan Krembangan Utara. Jurnal Berkala Epidemiologi, 2(1), 59-70

Ranuh, I. G. N., Hariyono, S., Hadinegoro., \& Soedjatmiko. (2008). Buku Imunisasi di Indonesia. Jakarta: Satgas Imunisasi IDAI

Senewe, M. S., Rompas, S., Lolong J. (2017). Analisis Faktor-Faktor yang Berhubungan dengan Kepatuhan Ibu dalam Pemberian Imunisasi Dasar di Puskesmas Tongkaina Kecamatan Bunaken Kota Madya Manado. E-Journal Keperawatan, 5(1), 1-12

Triana, V. (2016). Faktor yang Berhubungan dengan Pemberian Imunisasi Dasar Lengkap pada Bayi Tahun 2015. Jurnal Kesehatan Masyarakat Andalas, 10(2), 123-135. http://jurnal.fkm.unand.ac.id/index.php/jkma/

UNICEF. (2015). A Review of the Open Working Group Report on Sustainable from a Child Right Perspective. dari https://www.unicef.org/agenda2030/files/Post_2015_OWG_review_CR_FINAL.p df

Wati, L. (2013). Hubungan Pengetahuan, Pendidikan dan Informasi Ibu dengan Kelengkapan Imunisasi Dasar pada Anak 1-5 Tahun di Puskesmas Titue Kabupaten Pidie. Jurnal DIII kebidanan Stikes U'budiyah Banda Aceh

WHO. (2013). Immunization. Di akses 18 februari, 2017, dari http://www.who.int/topics/immunization/en

WHO. (2016). Progress and Challenges with Achieving Universal Immunization Coverage: 2015 Estimates of Immunization Coverage. dari https://www.unicef.org/immunization/files/unicef-who-immunization-coverage2015.pdf 